\title{
THE IMPACT OF THE M-LEARNING METHODOLOGY ON UNIVERSITY STUDENTS
}

\author{
Oscar Romero-Ramos (iD), Emilio Fernández-Rodríguez (iD), Iván López-Fernández (iD, \\ Rafael Merino-Marbán $\mathbb{D}$, Javier Benítez-Porres $\mathbb{D}$ \\ University of Málaga (Spain) \\ oromer@@uma.es,effernandez@uma.es,ivan@uma.es,rmerino@uma.es,benitez@uma.es
}

Received July 2021

Accepted October 2021

\begin{abstract}
Our goal in this paper is to analyze the impact of the implementation of M-Learning methodology on the motivation and assimilation of academic contents. A total of 283 university students participated in our study. They were assessed on two different occasions. For the assessment, a 10-question multiple-answer test set up in the Socrative mobile applications was used. To take into consideration the students' opinion on the experiment a satisfaction survey was used. The results from the global satisfaction survey show that the M-Learning methodology is perceived as a motivating tool $(74.6 \%)$ which generates a more pleasant environment in the classroom (71\%), increases student satisfaction attending classes (80.5\%) and helps students acquire learning contents better $(72.5 \%)$. The repetition and frequency of use of the application increased the final score in all groups (initial-final assessment: 5.9 vs 7.4 points). Data obtained suggest that the M-Learning methodology as a facilitator of content assimilation is useful in the academic environment and is a useful tool for improving the teaching-learning process too.
\end{abstract}

Keywords - Smartphone, ICT, Socrative, Physical education.

\section{To cite this article:}

Romero-Ramos, O., Fernández-Rodríguez, E., López-Fernández, I., Merino-Marbán, R., \&

Benitez-Porres, J. (2022). The Impact of the M-Learning methodology on university students. Journal

of Technology and Science Education, 12(1), 121-131. https://doi.org/10.3926/jotse.1422

\section{Introduction}

Using new technologies in the teaching-learning process has been recognized as a source of motivation for both students and teachers (Chernov, Klas \& Furman Shaharabani, 2021; Chung, Kallay, Anas, Bruno, Decamps, Evans et al., 2018; Guerrero, Jaume, Juiz \& Lera, 2016). Several terms may be found in the scientific literature to refer to this type of methodologies - Student Response Systems or Online Response Methodology (SRS), Learner Response Systems (LRS), Mobile Learning methodology (M-Learning), Social Learning Network (SLN) platforms, Bring Your Own Device (BYOD), among others.

Just two decades ago, studies such as Peters (2007) found that Mobile technologies were in common use in some commercial sectors, but their use purely for learning was rare. However, in those years, since 2005 the ideas of M-learning began to become popular in China, possibly it is a highly technical culture (Liu, Li \& Carlsson, 2010). Currently, this type of methodologies have acquired great importance, reaching a 
"forced" momentum during states of confinement during the pandemic due to Covid-19. At this time, M-Learning has been an essential tool in many cases, due to the familiarity of students with these mobile devices and the possible limitations of having computer equipment in the home of some families.

The Mobile Learning (M-Learning) methodology usually comes bundled as a cell phone application designed to facilitate the construction of knowledge, the problem solving processes and the autonomous development of diverse skills. Despite the ubiquity and flexibility of these devices, there has been minimal use of M-learning approaches in some education sectors and developments have tended to be more about the design of the tools than of the ensuing learning (Kearney, Schuck, Burden \& Aubusson, 2012).

According to Kearney at al. (2012), as mobile technologies develop, our challenge as educational researchers is to explore new pedagogical opportunities that respect the principles of authentic, collaborative and personalized learning, based on well-researched sociocultural tenets.

Upon the development of such real-time response system applications for smartphones as Socrative, Kahoot, Quizlet, Quizizz, etc., it is now easier than ever to assess students' knowledge very quickly.

The tools used in our study, Socrative, are applications very well suited for the type of teaching methodology involving immediate response systems where students do have access to the questions posed by the teacher through the "room or contest number." The site manager may generate or import multiple-choice questions, sort answers in the right order, ask true/false questions, pose short-answer questions, etc. (Figure 1).

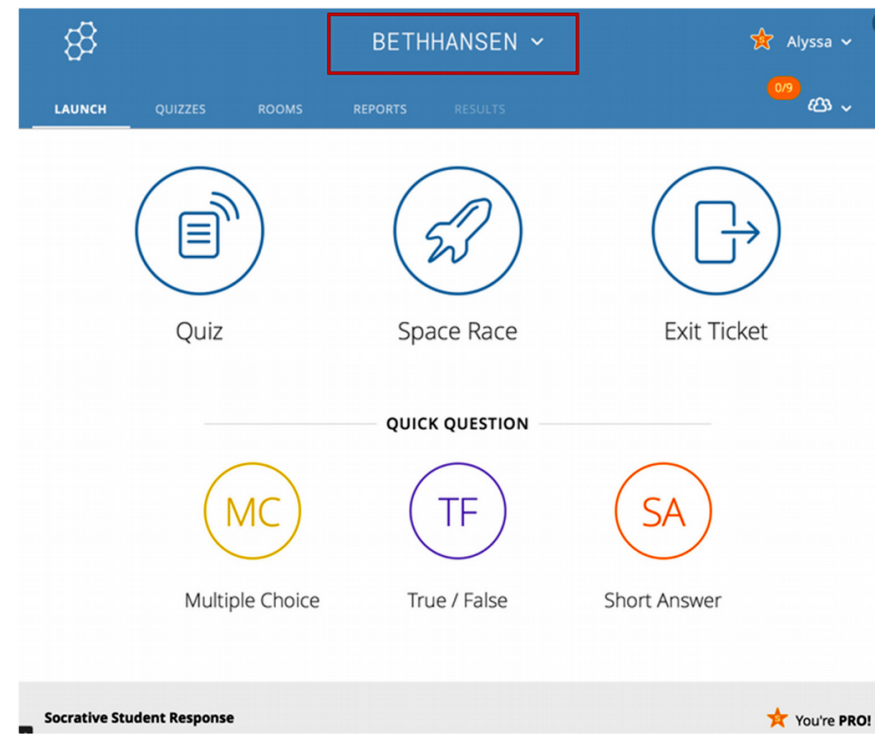

Figure 1. Type of questions on the socrative platform

Socrative provide statistics drawing on the answers given by students in real time. All statistical data may be displayed and analysed on the spot. Socrative's versions for computer and smart devices (smartphones and tablets) are free to use (teachers must register, though, also for free) and easy to handle. The low cost technology behind them has been recognized as having a great positive impact on the teaching learning process involving teachers and students (Al-Labadi \& Sant, 2021; Guerrero et al. 2016; Rodríguez, Ortiz \& Aguilar, 2018).

According to Ferreira, Moreira and Seruca (2013), the SRS methodology motivates students and boosts their interest in learning. Many fields of knowledge, such as reading comprehension (Cha, 2018), foreign language teaching-learning (Chou, Chang \& Lin, 2017; Yoon, 2017; Zou \& Lambert, 2017), physics and chemistry (Balta, Perera-Rodríguez \& Hervás-Gómez, 2018; Balta \& Tzafilkou, 2019; Santos, Grueso \& Trujillo-Cayado, 2016), engineering (Chernov et al., 2021) or healthcare (Aktekin, Celebi \& Aktekin, 2018; 
Munusamy, Osman, Riaz, Ali \& Mraiche, 2019), have implemented it by means of Socrative or Kahoot and have confirmed the positive impact it has on the motivation of students and the improvement of their attendance rates (Santos et al., 2016). There are also conceptual proposals to develop knowledge of technological pedagogical content among Physical Education teachers (Gawrisch, Richards \& Killian, 2019). Zou and Lambert (2017) also stress the very positive attitude that students show towards these digital tools. As noted by Balta and Tzafilkou (2019), there are really no significant gender differences in relation to the positive attitude shown by students towards the use of Socrative in the classroom.

SRS applications are remarkable for several reasons, notably for their immediate results and for the real-time feedback they give to teachers and students. Several scholars add that they can be, too, very useful tools to assess students very quickly (Chung et al., 2018) and diagnose weaknesses in the learning process in the classroom (Parra-Santos, Molina-Jordá, Casanova-Pastor \& Maiorano-Lauria, 2018).

As stated by Guarascio, Nemecek and Zimmerman (2017), students feel that Socrative help them participate in class fully and provide a better environment to ask answers and obtain questions.

However, the process of preparing teachers to use the M-Learning methodology is under-developed, and many studies have explored this subject in a positive way (Fombona, Pascual \& Ferra, 2020). In our opinion, teacher training in these methodologies is of vital importance to guarantee significant results among students, in this sense, Betancourt-Odio, Sartor-Harada, Ulloa-Guerra and Azevedo-Gomes (2021) confirmed the need for the development of training related to digital competencies and the ability to go beyond the selection and adaptation of resources, so that primary school teachers are able to promote innovation through technologies and, specifically, through the use of m-learning.. In some cases, studies show conflicting results even (this is possibly due, in part, to the methodology used, the types of questions asked, or the contents involved).

As far as the methodology used to assess the students' level of knowledge acquisition through M-Learning is concerned, it should be noted that some authors employ the focus/control group method (Chung et al., 2018), while others resort to the method of measuring the initial and final results of the same group (Santos et al., 2016) and even the results obtained by different groups belonging to different academic years (Abdulla, 2018).

Some scholars strongly endorse that students' knowledge acquisition may be improved to varying degrees by the M-Learning methodology (Balta et al., 2018; Santos et al., 2016).

Cha (2018) shows that a significant difference in the knowledge acquisition process may be found in the Socrative group's initial and final tests but finds no substantial differences between the Socrative group's and the non-Socrative group's results. Neither do Chung et al. (2018), who obtained similar scores in both the focus group and the control group.

Sometimes, a formative assessment performed in a traditional class may offer initially better results than the ones obtained in a BYOD (Bring Your Own Device) class (Chou et al., 2017). The reason behind this lies, in their opinion, in the fact that several students may not be familiar with this type of technological platforms. Later, however, the BYOD group obtained higher marks than the traditional class group in the area of contents absorbed and retained.

Kahoot and Socrative should be considered and used not only as tools to strengthen knowledge but, as noted by Parra-Santos et al. (2018), as instruments to diagnose weaknesses in the learning process in the classroom.

On using these two applications, students have found, however, a few hurdles - the consumption of cell phone Internet data, and the limitations of the Wi-Fi network used (Yoon, 2017).

In Table 1 we summarize - in the shape of potential strengths vs. weaknesses - all what we have mentioned so far about the M-Learning methodology. In this sense, the main disadvantage for the 
M-Learning application is related to the technological resources available by students and educational centers, due to the possible limitation of mobile data or Wi-Fi network, the non-availability of mobile devices compatible with the Apps and of students unfamiliar with digital environments, Sharma, Sharma, Sharma and Sharma (2021) state in their study that internet connectivity is the major area of concern to be looked upon for better m-learning. Some disadvantages were also documented in this study which includes distraction from studies and use of other applications (Sharma et al., 2021).

Various studies suggest that this digital divide is evident in rural centers or in disadvantaged areas, with differences according to sociodemographic and socioeconomic variables (Gómez-Navarro, Alvarado-López, Martínez-Domínguez \& Díaz de León-Castañeda, 2018; Katsinas \& Moeck, 2002; Shameem \& Sanjeetha, 2021; Scheerder, Van Deursen \& Van Dijk, 2017). Similarly, studies such as Aditya's (2021) suggest that digital learning problems were mostly encountered by teachers in rural areas.

Among the advantages of using M-Learning, the authors highlight the motivational variables (increased motivation and interest, improved rate of class attendance and participation), psychological variables (it allows to maintain anonymity and can reduce the level of anxiety of students before class questions) and in the learning process, some studies suggest that it facilitates the acquisition of knowledge, identifies gaps in content and allows the dissemination of results in real time. Of these advantages, and in our opinion, studies where these methodologies were maintained over time would be necessary, especially to analyze the behavior of motivational and learning variables.

In this paper we work under a double hypothesis: (i) the implementation of the M-Learning methodology in class may be useful to identify knowledge gaps in students; and (ii) identifying knowledge gaps in students may improve the assimilation of key academic contents and have a positive impact on initial and final assessments. Our goal in this paper is to analyse the impact of the implementation of a M-Learning on students' assimilation of academic contents and motivation in courses connected with the Physical Education field of knowledge within the framework of a university BA degree in Primary Education Teachers.

\begin{tabular}{|c|c|}
\hline Potential Weaknesses & Potential Strengths \\
\hline $\begin{array}{l}\text { - Use of cell phone Internet data } \\
\text { - Wi-Fi network limitations } \\
\text { - } \\
\text { - } \\
\text { Sevices must be compatible with apps } \\
\text { environments } \\
\text { - } \\
\text { distraction from studies by using other } \\
\text { apps. }\end{array}$ & 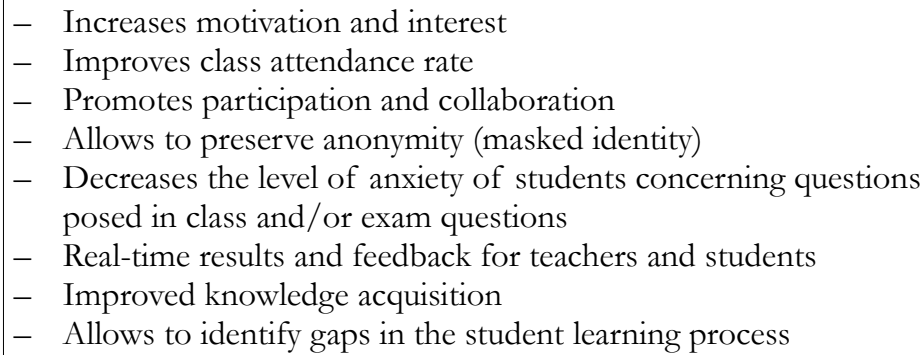 \\
\hline
\end{tabular}

Table 1. Strengths and weaknesses of the M-Learning methodology

\section{Design/methodology/approach}

\subsection{Participants}

A total of 283 students (65 men and 218 women) participated. All of them had an electronic device (a smartphone, a tablet or a laptop) and were asked to download, install and use Socrative during the different sessions. They were assessed with the Socrative application on two different occasions - at the beginning of the semester (as an initial assessment) and at the end of the semester (in the fashion of a summative assessment). Additionally, we used a global satisfaction survey.

The eligibility criteria for participation were the following: (a) students must be registered in any of the courses selected for the study; (b) they could not be repeaters; (c) they must have any such electronic devices that be compatible with Socrative; (d) they must show a minimum class attendance of $80 \%$; and (e) they had to commit to performing the two scheduled assessments plus the final questionnaire. 


\subsection{Materials}

To carry out our study, we decided to use the apps Socrative, because they both allow teachers to pose questions, quizzes, and games, and let students answer in real time from their own devices. In the classroom the applications were used also to learn about the students' previous knowledge on the course session or else to strengthen the contents that had already been studied during the semester. The results obtained were displayed during the teacher's session, or else be reported by e-mail or by means of an Excel or an online spreadsheet.

Additionally, we used a global satisfaction survey consisting of 30 items - 20 with a 5-degree Likert scale (Strongly Disagree - Disagree - Neutral - Agree - Strongly Agree), and 10 with a single checkbox, where ticking it involved agreeing. The questionnaire is available at the following address: https://docs.google.com/forms/d/e/1FAIpQLScE0pSZhvLHWDecZv26N7wJQBhTnPFD4wuEEvlOJgzfi1gK $\mathrm{ng} /$ viewform

\subsection{Methods}

For the initial and final assessments, a 10-question multiple answer test programmed in Socrative was used (of the four answer options, only one was correct). Students answered individually via their mobile devices. To analyse the assessment made by the students, as well as their recommendation for improvements, a satisfaction survey prepared by the teaching staff was used.

Once the last test (final assessment) was finished, the students who had participated in all the tests and met the eligibility criteria were asked to answer a satisfaction questionnaire on the use of the applications. Informed consent was obtained from all individual participants included in the study.

Finally, all the data obtained from the questionnaire and the assessment tests were fed into an SPSS matrix for further statistical analysis.

\subsection{Statistical Analysis}

It was performed by means of the SPSS 24.0 software (SPSS Inc. Chicago, Illinois). In order to know the respondents' global preferences, the survey different items were duly described. To compare the objective results in the initial and final assessment of each group, a test of comparison of means (a Student's t test for related samples) was also run.

\subsection{Results}

The results related to the average score of each group, as well as to the score obtained in each item of the battery of questions implemented in both applications, are shown in Figure 2.

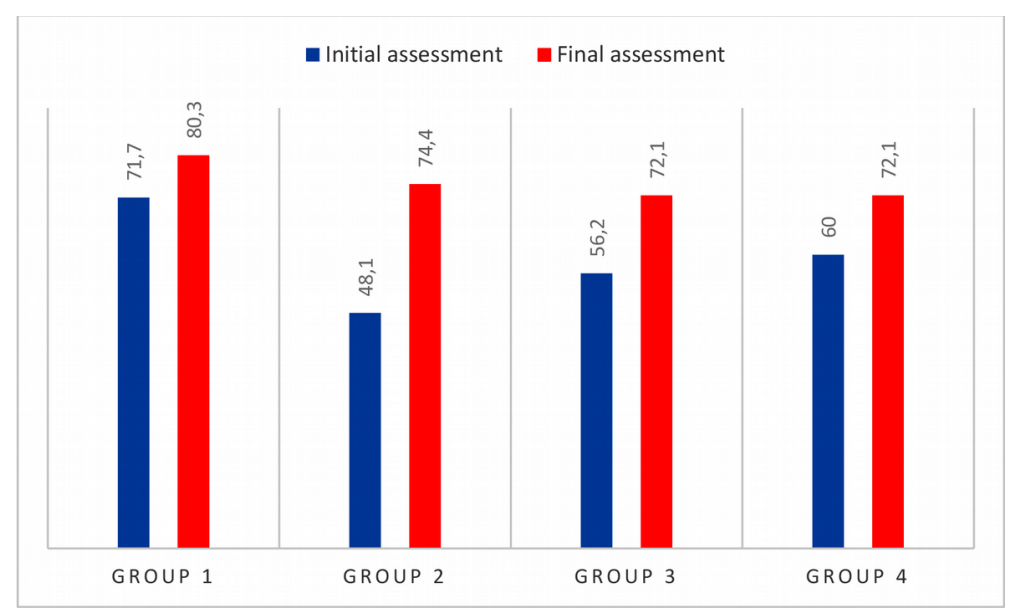

Figure 2. Results of the initial and final assessment of the students 
The difference between the initial and final knowledge test was 1.5 points (initial vs. final assessment: 5.9 points vs. 7.4 points).

The results obtained from the global satisfaction survey show that the M-Learning methodology is perceived as a tool (i) motivating (74.6\%), (ii) generating a more pleasant environment in the classroom (71\%), (iii) increasing class-attending student satisfaction (80.5\%), and (iv) making students feel that it helped them to acquire learning contents $(72.5 \%)$ better. The results can be seen graphically in Figure 3 .

The results of the single checkboxes of the satisfaction survey are shown in Figure 4. The items participation (89.8\%), motivation (89.4\%) and assistance to study $(65 \%)$ were the ones best valued by students.

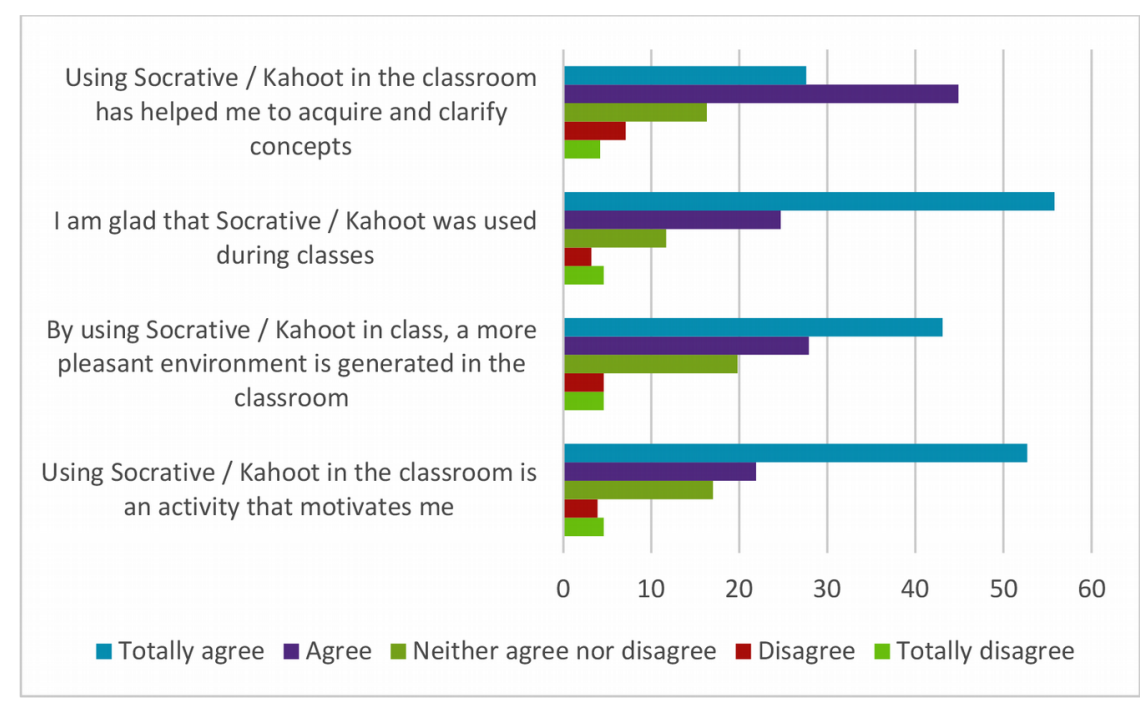

Figure 3. Degree of motivation, usefulness and student satisfaction

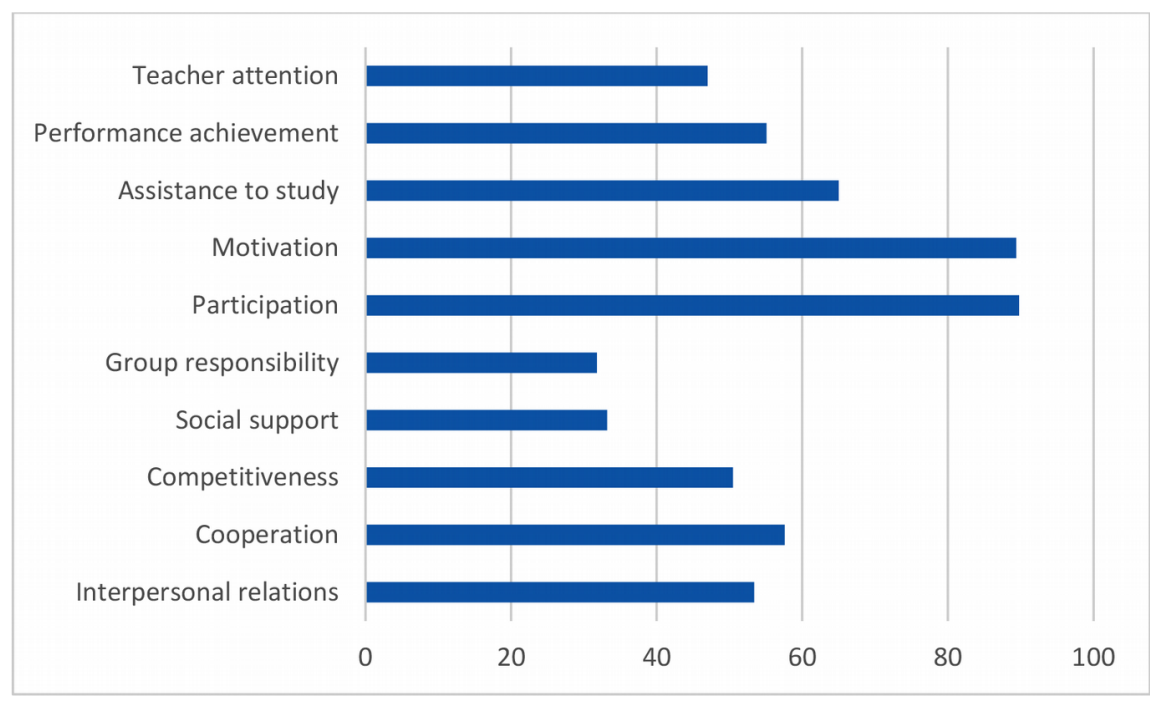

Figure 4. Assessment of students in the single checkboxes of the satisfaction survey

\subsection{Discussion}

In this paper we have evaluated the influence of the M-Learning methodology on the assimilation of academic contents and assessed the level of satisfaction and motivation of university students.

Our main results support the hypothesis that the use of M-Learning in class helps students acquire key learning concepts included the different course programs, thus increasing the performance of the final 
assessment by a point and a half on average as compared to the initial assessment. Different studies suggest that game-based student response systems increase performance and commitment while decreasing the level of anxiety in final exams compared to non-game-based student response systems (Abdulla, 2018; Chou et al., 2017; Guarascio et al., 2017; Turan \& Meral, 2018).

The social media item has been the one worst valued by students, possibly because our M-Learning proposal was put to work on an individual basis. Therefore, as can be seen in Figure 4, improvement of interpersonal relationships (53.4\%), cooperative drive (57.6\%), competitive drive (50\%), social support $(33.2 \%)$ and group responsibility $(31.8 \%)$ are among the worst valued items.

As for the level of student satisfaction and motivation, our results are very close to those obtained by other authors (Aktekin et al., 2018; Guerrero et al., 2016; Pintado \& de Cerio, 2017; Santos et al., 2016). Benitez-Porres (2018) obtained very high degrees of satisfaction with the use of Socrative in the course entitled Didáctica de los deportes (Sports Pedagogy) in the same university context as we have explored, where $92 \%$ of students reported high overall satisfaction in the use of the app in class. Furthermore, $96 \%$ of this course's students reported that they felt motivated with the educational experience (Benítez-Porres, 2018).

However, some authors believe that this technology-based methodology may have a negative impact on teachers (Tondeur, van Braak, Ertmer \& Ottenbreit-Leftwich, 2017) and students (Chen, Pedersen \& Murphy, 2012). In their opinion, there is some reluctance among teachers to use mobile devices regularly in the classroom because they may harm human communication and cause potential distractions. In our view, while this traditional conception of education might make sense at primary and middle levels of education, it is challenged by a few recent studies that highlight the advantage of using mobile technology to optimize the learning experience of university students. Some authors have already analysed the importance, advantages and difficulties of including and using mobile devices in higher education (Bicen \& Kocakoyun, 2018; Esteves, Pereira, Veiga, Vasco \& Veiga, 2018; Monte, Barreto \& Rocha, 2017).

The M-Learning methodology, taken as one whereby participation and collaboration are encouraged, has been also recently approached and benchmarked (Cha 2018; Guerrero et al. 2016; Kokina \& Juras 2017). Most studies confirm its high potential for increasing the levels of motivation, participation and positive attitude of students towards teaching contents, although, as Cha (2018) points out, the studies carried out so far apply the methodology on an ad hoc basis. We should then ask the question as to whether the increase in motivation in class could continue if the M-Learning methodology could be applied regularly no more but no less as the traditional ones. Results indicate that perceived near-term/long-term usefulness and personal innovativeness have significant influence on M-learning adoption intention; students' perception of near-term usefulness is mainly derived from a positive feeling of long-term usefulness (Liu et al., 2010).

The M-Learning methodology further allows to preserve anonymity during its implementation (Frías, Arce \& Flores-Morales, 2016), by easing out the participation of those students most reluctant to public performances. Masked identity, along with instant interaction, are the strengths best identified by students in the study conducted by Yoon (2017).

Finally, another potential strength of the M-Learning methodology could lie in the decrease in the level of anxiety of those students who do not like to be asked questions in class (Alejaldre-Briel, 2018). Turan and Meral (2018) showed that game-based response systems increase engagement and decrease the level of anxiety during tests, compared to non-game-based student response systems. 


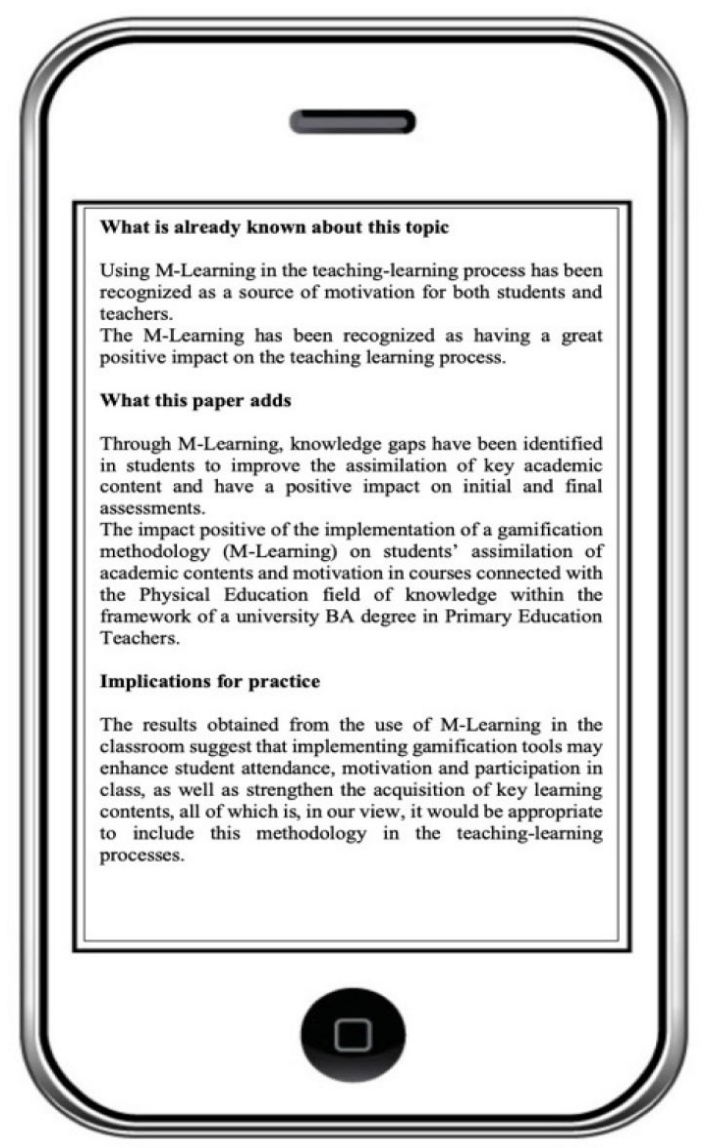

Figure 5. Assessment of students in the single checkboxes of the satisfaction survey

\section{Conclusions}

The results obtained from the use of the apps Socrative in the classroom suggest that implementing M-Learning tools may enhance student attendance, motivation and participation in class, as well as strengthen the acquisition of key learning contents - all of which is, in our view, critical to generate meaningful learning in the classroom. According to the results of our study, we could affirm that the use of the Socrative application in class has proven to be positive in the learning process, helping in the acquisition of new knowledge.

Group strategies and tasks could be implemented through these two apps, so as to improve such social aspects as interaction between students and teachers, student cooperation, and group responsibility, all of which have been the worst valued ones in our study.

In our opinion, it would be very useful for the furtherance of the subject-matter approached herein to design and carry out several longitudinal studies aimed at measuring the impact of the apps over a complete cycle in the same degree and its relationship with the qualifications obtained (academic performance) in different courses.

\section{Declaration of Conflicting Interests}

The authors declared no potential conflicts of interest with respect to the research, authorship, and/or publication of this article.

\section{Funding}

The authors received no financial support for the research, authorship, and/or publication of this article. 


\section{References}

Abdulla, M.H. (2018). The use of an online student response system to support learning of Physiology during lectures to medical students. Education and Information Technologies, 23(6), 2931-2946. https://doi.org/10.1007/s10639-018-9752-0

Aditya, D.S. (2021). Embarking digital learning due to COVID-19: Are teachers ready?. Journal of Technology and Science Education, 11(1), 104-116. https://doi.org/10.3926/jotse.1109

Aktekin, N.C., Celebi, H., \& Aktekin, M. (2018). Let's Kahoot! Anatomy. International Journal of Morphology, 36(2), 716-721. https://doi.org/10.4067/S0717-95022018000200716

Al-Labadi, L., \& Sant, S. (2021). Enhance learning experience using technology in class. Journal of Technology and Science Education, 11(1), 44-52. https://doi.org/10.3926/jotse.1050

Alejaldre-Briel, L. (2018). Mobilizing the teaching and learning of Spanish as a foreign language to raise spontaneous participation: A case study of Thai university students. El Guiniguada. Revista de investigaciones y experiencias en Ciencias de la Educación, 27, 55-70. https://doi 10.20420/ElGuiniguada.2018.206

Balta, N., Perera-Rodríguez, V.H., \& Hervás-Gómez, C. (2018). Using socrative as an online homework platform to increase students' exam scores. Education and Information Technologies, 23(2), 837-850. https://doi.org/10.1007/s10639-017-9638-6

Balta, N., \& Tzafilkou, K. (2019). Using Socrative software for instant formative feedback in physics courses. Education and Information Technologies, 24(1), 307-323. https://doi.org/10.1007/s10639-018-9773-8

Benítez-Porres, J. (2018). Aplicación de la metodología mobile learning en la Universidad de Málaga. In T.-Vallet-Bellmunt \& T. Martínez-Fernández (Eds.), DIMEU: Dispositivos Móviles en la Educación Universitaria, 25-32. Universitat Jaume I.

Betancourt-Odio, M.A., Sartor-Harada, A., Ulloa-Guerra, O., \& Azevedo-Gomes, J. (2021). Self-perceptions on digital competences for m-learning and education sustainability: A study with teachers from different countries. Sustainability, 13(1), 343. https://doi.org/10.3390/su13010343

Bicen, H., \& Kocakoyun, S. (2018). Perceptions of Students for Gamification Approach: Kahoot as a Case Study. International Journal of Emerging Technologies in Learning, 13(2), 72-93.

https://doi.org/10.3991/ijet.v13i02.7467

Cha, Y. (2018). Using a student response system (Socrative) as a pre- reading method in an EFL reading environment. STEM Journal, 19(2), 95-119. https://doi.org/10.16875/stem.2018.19.2.95

Chen, C.Y., Pedersen, S., \& Murphy, K.L. (2012). The influence of perceived information overload on student participation and knowledge construction in computer-mediated communication. Instructional Science, 40(2), 325-349. https://doi.org/10.1007/s11251-011-9179-0

Chernov, V., Klas, S., \& Furman Shaharabani, Y. (2021). Incorporating Kahoot! in core engineering courses: Student engagement and performance. Journal of Technology and Science Education, 11(2), 486-497. https://doi.org/10.3926/jotse.1269

Chou, P.N., Chang, C.C., \& Lin, C.H. (2017). BYOD or not: A comparison of two assessment strategies for student learning. Computers in Human Behavior, 74, 63-71. https://doi.org/10.1016/j.chb.2017.04.024

Chung, H., Kallay, T., Anas, N., Bruno, D., Decamps, J., Evans, D. et al. (2018). Using an Audience Response System Smartphone App to Improve Resident Education in the Pediatric Intensive Care Unit. Journal of Medical Education and Curricular Development, 5, 2382120518770674.

https://doi.org/10.1177/2382120518770674 
Esteves, M., Pereira, A., Veiga, N., Vasco, R., \& Veiga, A. (2018). The Use of New Learning Technologies in Higher Education Classroom: A Case Study. International Journal of Engineering Pedagogy, 8(2), 115-127. https://doi.org/10.3991/ijep.v8i2.8146

Ferreira, M.J., Moreira, F., \& Seruca, I. (2013). A traditional school towards a new dimension: Social learning. The Proceedings of the Information Systems Education Conference, 30(2684), San Antonio, Texas, 7-10 nov. 2013.

Fombona, J., Pascual, M., \& Ferra, M.P. (2020). Analysis of the educational impact of M-Learning and related scientific research. Journal of New Approaches in Educational Research (NAER Journal), 9(2), 167-180. https://doi.org/10.7821/naer.2020.7.470

Frías, M.V., Arce, C., \& Flores-Morales, P. (2016). Uso de la plataforma socrative. com para alumnos de Química General. Educación quimica, 27(1), 59-66. https://doi.org/10.1016/j.eq.2015.09.003

Gawrisch, D.P., Richards, K.A.R., \& Killian, C.M. (2019). Integrating Technology in Physical Education Teacher Education: A Socialization Perspective. Quest, 1-18. https://doi.org/10.1080/00336297.2019.1685554

Gómez-Navarro, D.A., Alvarado-López, R.A., Martínez-Domínguez, M., \& Díaz de León-Castañeda, C. (2018). The digital divide: A conceptual revision and methodological contributions for its study in Mexico. Entreciencias: diálogos en la sociedad del conocimiento, 6(16), 47-62. https://doi.org/10.22201/enesl.20078064e.2018.16.62611

Guarascio, A.J., Nemecek, B.D., \& Zimmerman, D.E. (2017). Evaluation of students' perceptions of the Socrative application versus a traditional student response system and its impact on classroom engagement. Currents in Pharmacy Teaching and Learning, 9(5), 808-812. https://doi.org/10.1016/j.cptl.2017.05.011

Guerrero, C., Jaume, A., Juiz, C., \& Lera, I. (2016). Use of Mobile Devices in the Classroom to Increase Motivation and Participation of Engineering University Students. Ieee Latin America Transactions, 14(1), 411-416. https://doi.org/10.1109/Tla.2016.7430109

Katsinas, S.G., \& Moeck, P. (2002). The digital divide and rural community colleges: Problems and prospects. Community College Journal of Research and Practice, 26(3), 207-224. https://doi.org/10.1080/106689202317245419

Kearney, M., Schuck, S., Burden, K., \& Aubusson, P. (2012). Viewing mobile learning from a pedagogical perspective. Alt-J-Research In Learning Technology, 20(1). https://doi.org/10.3402/rlt.v20i0/14406

Kokina, J., \& Juras, P.E. (2017). Using Socrative to Enhance Instruction in an Accounting Classroom. Journal of Emerging Technologies in Accounting, 14(1), 85-97. https://doi.org/10.2308/jeta-51700

Liu, Y., Li, H., \& Carlsson, C. (2010). Factors driving the adoption of m-learning: An empirical study. Computers \& Education, 55(3), 1211-1219. https:// doi.org/10.1016/j.compedu.2010.05.018

Monte, W.S., Barreto, M.M., \& Rocha, A.B. (2017). Gamification and the Web 2.0: planning teaching-learning process. Holos, 33(3), 90-97. https://doi.org/10.15628/holos.2017.5759

Munusamy, S., Osman, A., Riaz, S., Ali, S., \& Mraiche, F. (2019). The use of Socrative and Yammer online tools to promote interactive learning in pharmacy education. Currents in Pharmacy Teaching and Learning, 11(1), 76-80. https://doi.org/10.1016/j.cptl.2018.09.021

Parra-Santos, T., Molina-Jordá, J.M., Casanova-Pastor, G., \& Maiorano-Lauria, L.P. (2018). Gamification for formative assessment in the framework of engineering learning. In Proceedings of the Sixth International Conference on Technological Ecosystems for Enhancing Multiculturality (61-65). ACM. https://doi.org/10.1145/3284179.3284193 
Peters, K. (2007). M-Learning: Positioning educators for a mobile, connected future. The International Review of Research in Open and Distributed Learning, 8(2).

Pintado, A.B., \& de Cerio, J.M.D. (2017). Socrative: A tool to dinamyze the classroom. Wpom-Working Papers on Operations Management, 8, 72-75. https://doi.org/10.4995/wpom.v8i0.7167

Rodríguez, A.L., Ortiz, J.F.Z., \& Aguilar, M.I.L. (2018). Using Online Educational Resources at the High School level: Development of teaching competences of teachers. CPU-E Revista de Investigacion Educativa, (26), 114-135.

Santos, J., Grueso, E., \& Trujillo-Cayado, L.A. (2016). Uso de una aplicación móvil para aumentar la motivación del alumnado en formulación y nomenclatura química. Afinidad, 74(576).

Scheerder, A., Van Deursen, A., \& Van Dijk, J. (2017). Determinants of Internet skills, uses and outcomes. A systematic review of the second-and third-level digital divide. Telematics and informatics, 34(8), 1607-1624. https://doi.org/10.1016/j.tele.2017.07.007

Shameem, A.L.M.A., \& Sanjeetha, M.B.F. (2021). M-Learning Systems Usage: A Perspective from Students of Higher Educational Institutions in Sri Lanka. The Journal of Asian Finance, Economics and Business, 8(8), 637-645. https://doi.org/10.13106/JAFEB.2021.VOL8.NO8.0637

Sharma, P., Sharma, N., Sharma, N., \& Sharma, D. (2021). Unmasking the impact of m-learning on medical undergraduates. International Journal of Academic Medicine, 7(1), 10.

https://doi.org/10.4103/IJAM.IJAM_99_20

Tondeur, J., van Braak, J., Ertmer, P.A., \& Ottenbreit-Leftwich, A. (2017). Understanding the relationship between teachers' pedagogical beliefs and technology use in education: a systematic review of qualitative evidence. Educational Technology Research and Development, 65(3), 555-575.

https://doi.org/10.1007/s11423-016-9481-2

Turan, Z., \& Meral, E. (2018). Game-Based versus to Non-Game-Based: The Impact of Student Response Systems on Students' Achievements, Engagements and Test Anxieties. Informatics in Education, 17(1), 105-116. https://doi.org/10.15388/infedu.2018.07

Yoon, S.Y. (2017). Using Learner Response Systems in EFL Classrooms: Students' Perspectives and Experience. Multimedia-Assisted Language Learning, 20(2), 36-58.

Zou, D., \& Lambert, J. (2017). Feedback methods for student voice in the digital age. British Journal of Educational Technology, 48(5), 1081-1091. https://doi.org/10.1111/bjet.12522

Published by OmniaScience (www.omniascience.com)

Journal of Technology and Science Education, 2022 (www.jotse.org)

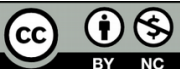

Article's contents are provided on an Attribution-Non Commercial 4.0 Creative commons International License.

Readers are allowed to copy, distribute and communicate article's contents, provided the author's and JOTSE journal's names are included. It must not be used for commercial purposes. To see the complete licence contents, please visit https://creativecommons.org/licenses/by-nc/4.0/. 